\title{
Effects of low dietary cation-anion difference induced by ruminal ammonium chloride infusion on performance, serum, and urine metabolites of lactating dairy cows
}

\author{
Kun Wang ${ }^{1, a}$, Xuemei Nan ${ }^{1, a}$, Puyi Zhao ${ }^{1}$, Wei Liu', James K. Drackley², Shijie Liư ${ }^{3}$, \\ Kaizhan Zhang ${ }^{4}$, and Dengpan $\mathrm{Bu}^{1,5,6, *}$
}

\author{
* Corresponding Author: Dengpan Bu \\ Tel: +86-010-62813901, Fax: +86-010-62815988, \\ E-mail: budengpan@126.com \\ 'State Key Laboratory of Animal Nutrition, Institute \\ of Animal Science, Chinese Academy of Agricultural \\ Sciences, Beijing 100193, China \\ 2 Department of Animal Sciences, University of Illinois, \\ Urbana IL 61801, USA \\ ${ }^{3}$ China Feed Industry Association, Beijing 100125, \\ China \\ ${ }^{4}$ Beijing Sino Farm, Beijing 100125, China \\ ${ }^{5}$ CAAS-ICRAF Joint Lab on Agroforestry and \\ Sustainable Animal Husbandry, World Agroforestry \\ Centre, East and Central Asia, Beijing 100193, China \\ ${ }^{6}$ Hunan Co-Innovation Center of Animal Production \\ Safety, CICAPS, Changsha, Hunan 410128, China \\ a These authors contributed equally to this work. \\ ORCID \\ Kun Wang \\ https://orcid.org/0000-0002-6855-8743 \\ Xuemei Nan \\ https://orcid.org/0000-0002-1483-4036 \\ Puyi Zhao \\ https://orcid.org/0000-0002-0518-3788 \\ Wei Liu \\ https://orcid.org/0000-0001-5616-2154 \\ James K. Drackley \\ https://orcid.org/0000-0002-4560-5594 \\ Shijie Liu \\ https://orcid.org/0000-0002-3673-5194 \\ Kaizhan Zhang \\ https://orcid.org/0000-0001-8798-1558 \\ Dengpan Bu
}

https://orcid.org/0000-0003-1548-5509

Submitted Jul 18, 2017; Revised Sept 18, 2017; Accepted Oct 23, 2017
Objective: The objective of the present study was to determine ammonium chloride tolerance of lactating dairy cows, by examining effects of negative dietary cation anion difference (DCAD) induced by ruminal ammonium chloride infusion on performance, serum and urine minerals, serum metabolites and enzymes of lactating dairy cows.

Methods: Four primiparous lactating Chinese Holstein cows fitted with ruminal cannulas were infused with increasing amounts $(0,150,300$, or $450 \mathrm{~g} / \mathrm{d})$ of ammonium chloride in a crossover design. The DCAD of the base diet was $279 \mathrm{mEq} / \mathrm{kg}$ dry matter $(\mathrm{DM})$ using the DCAD formula $(\mathrm{Na}+\mathrm{K}-\mathrm{Cl}-\mathrm{S}) / \mathrm{kg}$ of DM. Ammonium chloride infusion added the equivalent of $0,128,330$, and $536 \mathrm{mEq} / \mathrm{kg} \mathrm{DM}$ of $\mathrm{Cl}$ in treatments. According to the different dry matter intakes (DMI), the resulting actual DCAD of the four treatments was $279,151,-51$, and $-257 \mathrm{mEq} / \mathrm{kg} \mathrm{DM}$, respectively.

Results: DMI decreased linearly as DCAD decreased. Yields of milk, $4 \%$ fat-corrected milk, energy-corrected milk, milk fat, and milk protein decreased linearly as DCAD decreased. Concentrations of milk protein and milk urea nitrogen increased linearly with decreasing DCAD. Concentration of $\mathrm{Cl}-$ in serum increased linearly and concentration of PO43- in serum increased quadratically as DCAD decreased. Urine $\mathrm{pH}$ decreased linearly and calculated urine volume increased linearly with decreasing DCAD. Linear increases in daily urinary excretion of $\mathrm{Cl}^{-}, \mathrm{Ca}^{2+}, \mathrm{PO}_{4}^{3-}$, urea $\mathrm{N}$, and ammonium were observed as DCAD decreased. Activities of alanine aminotransferase, aspartate aminotransferase, and $\gamma$-glutamyl transferase in serum and urea $\mathrm{N}$ concentration in serum increased linearly as DCAD decreased. Conclusion: In conclusion, negative DCAD induced by ruminal ammonium chloride infusion resulted in a metabolic acidosis, had a negative influence on performance, and increased serum enzymes indicating potential liver and kidney damage in lactating dairy cows. Daily ammonium chloride intake by lactating dairy cows should not exceed $300 \mathrm{~g}$, and $150 \mathrm{~g} / \mathrm{d}$ per cow may be better.

Keywords: Lactating Dairy Cow; Dietary Cation Anion Difference; Ammonium Chloride; Serum and Urine Metabolites

\section{INTRODUCTION}

In dairy cows, the concept of negative dietary cation anion difference (DCAD, defined as milliequivalents of $\mathrm{Na}+\mathrm{K}-\mathrm{Cl}-\mathrm{S}$ per kg of feed dry matter [DM]) has been used in dry cow nutrition to reduce the incidence of parturient paresis [1,2]. Interest has also grown in the potential effects of DCAD on lactating dairy cows. Tucker et al [3] were the first to evaluate $\mathrm{DCAD}$ in lactating dairy cows, and their results reported that milk yield was $8.6 \%$ higher when a diet with DCAD of $20 \mathrm{vs}-10 \mathrm{mEq}(\mathrm{Na}+\mathrm{K}-\mathrm{Cl}) / 100 \mathrm{~g}$ of $\mathrm{DM}$ was fed. Similar re- 
sults have been reported that increases in milk yield and dry matter intake (DMI) when DCAD increased from -79.4 to $+324.4 \mathrm{mEq} / \mathrm{kg}$ of DM [4] and from +120.4 to $+464.1 \mathrm{mEq} / \mathrm{kg}$ of DM [5]. Likewise, addition of $\mathrm{Cl}$ salts has negative effects. Escobosa et al [6] reported that milk production reduced when cows were supplemented with anions $\left(2.28 \% \mathrm{CaCl}_{2}\right)$. Yen et al [7] found that high dietary $\mathrm{CaCl}_{2}$ limited intake in swine through a $\mathrm{Cl}$-induced metabolic acidosis, an indication that altered acid-base status affects animal performance. Thus, it is well known that low DCAD results in negative effects on DMI and milk production.

In China, regulatory authorities require demonstrations of product safety to animals before new products can be registered. Such demonstrations may include whether a feed approved for one use, such as for creating a negative DCAD in non-lactating cows, might have detrimental effects if accidentally used in another application within that species, such as feeding ammonium chloride $\left(\mathrm{NH}_{4} \mathrm{Cl}\right)$ to lactating cows. Therefore, further efforts need to be made to examine effects of $\mathrm{NH}_{4} \mathrm{Cl}$ on milk performance, serum, and urine metabolites of lactating dairy cows under Chinese feeding conditions in order to determine $\mathrm{NH}_{4} \mathrm{Cl}$ tolerance of lactating dairy cows.

$\mathrm{NH}_{4} \mathrm{Cl}$, as a feed additive, has been widely used in livestock production. Since Leoschke and Elvehjem [8] reported prevention of urinary calculi formation in mink by decreasing urinary $\mathrm{pH}$ with addition of $\mathrm{NH}_{4} \mathrm{Cl}$, it has been applied as an acidity regulator in feed for bovines [9,10], goats [11-13], sheep [14], dogs [15], cats [16], and horses [17]. Administration of $\mathrm{NH}_{4} \mathrm{Cl}$ also has been widely used to create a model of metabolic acidosis in both humans and animals $[18,19]$. Common chloride salts used to decrease DCAD for dry cows include $\mathrm{MgCl}_{2}, \mathrm{CaCl}_{2}$, and $\mathrm{NH}_{4} \mathrm{Cl}$. Compared to $\mathrm{Mg}^{+2}$ and $\mathrm{Ca}^{+2}, \mathrm{NH}_{4}^{+}$does not result in overload of essential elements to the cow or environment. However, as a source of nonprotein nitrogen (NPN), $\mathrm{NH}_{4}^{+}$poses the risk of ammonia toxicity. However, Crookshank et al [20] reported that $\mathrm{NH}_{4} \mathrm{Cl}$ can be used as a source of NPN without clinical signs of ammonia toxicity when added up to $1 \%$ of the total ration. Bartley et al [21] showed that rumen $\mathrm{pH}$ was more clearly associated with ammonia toxicity than rumen ammonia. $\mathrm{NH}_{4} \mathrm{Cl}$ dissociates into $\mathrm{NH}_{4}^{+}$and $\mathrm{Cl}$ - ions in the rumen without increasing rumen $\mathrm{pH}$ as occurs when urea is hydrolyzed to ammonia [22]. Kertz et al [23] found that low rumen $\mathrm{pH}$ traps ammonia within the rumen, in which case high rumen ammonia should not produce sublethal or lethal ammonia toxicity.

The main objective of this study was to determine $\mathrm{NH}_{4} \mathrm{Cl}$ tolerance of lactating dairy cows, by examining effects of negative $\mathrm{DCAD}$ induced by ruminal $\mathrm{NH}_{4} \mathrm{Cl}$ infusion on performance, serum and urine minerals, serum metabolites and enzymes of lactating dairy cows. The second objective of this study was to determine whether $\mathrm{NH}_{4} \mathrm{Cl}$ could pose risk of ammonia toxicity under the conditions of the present study.

\section{MATERIALS AND METHODS}

\section{Animals, diets, and experimental design}

All animals involved in this study were cared for according to principles of the Chinese Academy of Agricultural Sciences Animal Care and Use Committee (Beijing, China). Four primiparous Chinese Holstein cows (body weight $[\mathrm{BW}]=556 \pm 39$ $\mathrm{kg}$, days in milk $=357 \pm 2 \mathrm{~d}$ ) that had been fitted previously with ruminal cannulas (10-cm center diameter; Bar Diamond, Parma, ID, USA) were housed in a free-stall barn equipped with a computerized monitoring system (RIC system, Insentec B.V., Marknesse, the Netherlands). The system automatically identified individual cows by ear tags and recorded their feeding time and duration, as well as the quantity of feed intake at each meal. The basal diet (Table 1) was formulated to meet or exceed nutrient requirements for energy, protein, minerals, and vitamins according to the Feeding Standards of Dairy Cattle (Ministry of Agriculture of P. R. China recommendations, 2004). The diet was fed as a total mixed ration (TMR) 3 times daily $(0730,1330$, and $2000 \mathrm{~h})$ to ensure ad libitum intake, allowing for $5 \%$ orts, along with free access to water. Cows were milked 3 times daily, at 0800, 1400, and $2030 \mathrm{~h}$.

The experimental design (Table 2 ) was as used previously $[24,25]$. Cows were administered the 2 treatments in a crossover design: an $\mathrm{NH} 4 \mathrm{Cl}$ solution at varying concentrations versus water as control. Each experimental period of the crossover design lasted $4 \mathrm{wk}$ (Table 2). A cow in each period was thus considered a main plot. To prepare the cows for the first period, there was an initial 1-wk adaptation during which all cows were infused with water. During the 4-wk period, graded amounts of $\mathrm{NH}_{4} \mathrm{Cl}(0,150,300$, and $450 \mathrm{~g} / \mathrm{d})$ were administered to the treated cows with each amount coinciding with 1 of the $4 \mathrm{wk}$ (i.e., the sub-plots of the split plot). Control cows continued to be infused with the same amount of water. For the treated cows, we determined based on preliminary experiments that it was not desirable physiologically to randomize the administration of these 4 amounts. Therefore, as in the study by Drackley et al [25], we allowed the cows to adapt to each amount of $\mathrm{NH}_{4} \mathrm{Cl}$ before receiving a higher amount. After period 1, all cows were returned to water infusion for a 2 -wk washout period. Then period 2 was initiated for another 4 wk with the same 4 cows in opposite treatment groups. With this design, the effects of week of administration and amount of $\mathrm{NH}_{4} \mathrm{Cl}$ were confounded. Because control cows received water infusion each week, against which the treated cows were compared, the confounding is not relevant (see description of statistical analysis).

During the experiment periods, cows were fed with a TMR 3 times daily $(0730,1330$, and $2000 \mathrm{~h})$ to ensure ad libitum intake and infused 3 times daily after feeding $30 \mathrm{~min}$. The infused $\mathrm{NH}_{4} \mathrm{Cl}$ solution was freshly prepared before each infusion by dissolving one-third of the daily dose of $\mathrm{NH}_{4} \mathrm{Cl}$ for each 
Table 1. Ingredient and chemical composition of basal diets (\% of DM)

\begin{tabular}{|c|c|}
\hline Item & Content \\
\hline \multicolumn{2}{|l|}{ Ingredient } \\
\hline Corn silage & 21.59 \\
\hline Alfalfa hay & 11.39 \\
\hline Extruded soybeans & 1.68 \\
\hline Soybean meal & 10.15 \\
\hline Flaked corn & 15.61 \\
\hline Ground corn & 8.23 \\
\hline Corn DDGS & 8.57 \\
\hline Whole cottonseed & 6.51 \\
\hline Rapeseed meal & 1.24 \\
\hline Apple pomace & 1.72 \\
\hline Beet pulp & 4.79 \\
\hline Salt & 0.38 \\
\hline Calcium carbonate $38 \%$ & 1.05 \\
\hline Sodium bicarbonate & 1.39 \\
\hline Magnesium oxide & 0.24 \\
\hline Potassium bicarbonate & 0.91 \\
\hline Dicalcium phosphate & 0.05 \\
\hline Monensin & 0.01 \\
\hline Zeolite & 0.05 \\
\hline Fat $^{1)}$ & 1.77 \\
\hline Yeast culture ${ }^{2)}$ & 0.62 \\
\hline Syrup & 1.48 \\
\hline Premix ${ }^{3)}$ & 0.57 \\
\hline $\mathrm{CP}$ & 16.27 \\
\hline ADF & 23.33 \\
\hline NDF & 34.39 \\
\hline $\mathrm{NE}_{L}^{4)}(\mathrm{Mcal} / \mathrm{kg})$ & 1.80 \\
\hline Ether extract & 5.24 \\
\hline Ash & 8.24 \\
\hline $\mathrm{Ca}$ & 0.75 \\
\hline$P$ & 0.32 \\
\hline $\mathrm{Na}$ & 0.54 \\
\hline K & 1.33 \\
\hline $\mathrm{Cl}$ & 0.61 \\
\hline $\mathrm{Mg}$ & 0.44 \\
\hline$S$ & 0.20 \\
\hline$D C A D^{5)}(\mathrm{mEq} / \mathrm{kg} \mathrm{DM})$ & 279 \\
\hline
\end{tabular}

DM, dry matter; DDGS, distillers dried grains with solubles; $C P$, crude protein; ADF, acid detergent fiber; NDF, neutral detergent fiber; NEL, net energy for lactation; $D C A D$, dietary cation anion difference.

1) Bergafat, a saturated free fatty acid supplement (Berg+Schmidt, Germany).

${ }^{2)}$ Diamond V XP yeast culture supplement (Diamond V, Cedar Rapids, lowa, USA).

${ }^{3)}$ Premix composition per kilogram: 1,230 mg of Cu (minimum [min]), 4,950 mg of $\mathrm{Zn}(\mathrm{min}), 1,760 \mathrm{mg}$ of $\mathrm{Mn}(\mathrm{min}), 50 \mathrm{mg}$ of I (min), $61 \mathrm{mg}$ of Se (min), $37 \mathrm{mg}$ of $\mathrm{Co}$ (min), 504,800 IU of vitamin A (min), 88,800 IU of vitamin $D_{3}$ (min), and 2,100 IU of vitamin $E$ (min), $700 \mathrm{mg}$ of vitamin $B_{3}$ (min).

4) Estimated according to NRC [52].

5) Calculated by the formula: DCAD, mEq/kg DM $=(\% \mathrm{Na} / 0.0023+\% \mathrm{~K} / 0.0039)$ $-(\% \mathrm{Cl} / 0.00355+\% \mathrm{~S} / 0.0016)$

treatment amount in $600 \mathrm{~mL}$ of distilled water. Solutions were infused into the rumen manually by opening the ruminal cannulas and administering the solutions into the rumen.

\section{Sampling and measurements}

The TMR and orts from individual cows were sampled on the last $3 \mathrm{~d}$ of each week and analyzed for DM content by drying samples at $50^{\circ} \mathrm{C}$ for $48 \mathrm{~h}$ in a forced-air oven [26]. The samples were ground to pass through a 6-mm screen using a Wiley mill (Thomas Scientific, Swedesboro, NJ, USA), and composited by cow. Subsamples of TMR and orts were ground to pass through a 1-mm screen to analyze crude protein (CP), ether extract, acid detergent fiber, and ash according to AOAC International [27]. The contents of neutral detergent fiber were obtained according to Van Soest et al [28], with $\alpha$-amylase and without sodium sulfite. The dietary contents of $\mathrm{Ca}, \mathrm{P}, \mathrm{Mg}$, $\mathrm{Na}, \mathrm{K}, \mathrm{Cl}$, and $\mathrm{S}$ were determined at an official laboratory (National Food Safety Supervision and Inspection Center, Beijing, China) by Inductively Coupled Plasma-Optical Emission Spectrometer (Optima 8000DV, Perkin-Elmer, Shanghai, China).

Milk production was recorded daily and milk samples were collected on the last $3 \mathrm{~d}$ of each experimental week. Milk samples were collected at each milking of every sampling day, and the 3 samples from each day were pooled in a proportion of 4:3:3 by volume (this ratio reflecting the milk yield of morning, afternoon, and night) into $50-\mathrm{mL}$ subsamples to which was added 1 milk preservative tablet (Bromopol, D and F Control Systems, San Ramon, CA, USA). This subsample was then stored at $4^{\circ} \mathrm{C}$ for future analysis of milk composition by infrared analysis [29] with a Foss-Milkoscan TM Minor (MilkoScan FT120, Foss Electric A/S, Hillerod, Denmark). Milk urea $\mathrm{N}$ was measured by an assay kit (urease method) purchased from Nanjing Jiancheng Bioengineering Institute (Nanjing, China).

Blood was sampled from the coccygeal vein on $\mathrm{d} 7$ of each experimental week $3 \mathrm{~h}$ after the a.m. feeding. Blood samples collected in serum separator tubes (Serum Clot Activator, Greiner Bioone GmbH, A-4550 Kremsmunster, Austria) were allowed to clot for $30 \mathrm{~min}$ at room temperature and stored in the refrigerator overnight, and serum was harvested by centrifugation at $3,000 \times g$ for $15 \mathrm{~min}$ at $4^{\circ} \mathrm{C}$ [30]. Serum was stored at $-20^{\circ} \mathrm{C}$ for future analysis of alanine aminotransferase (ALT; Reitman-Frankel colorimetric method), aspartate aminotransferase (AST; Reitman-Frankel colorimetric method), $\gamma$-glutamyl transferase (GGT; Szasz method), urea N (urease method), creatinine (picric acid colorimetric method), and uric acid (phosphotungstic acid colorimetric method), using an automated chemistry analyzer (Hitachi 7080, Beijing CIC Clinical Laboratory, Beijing, China). Assay kits for ALT, AST, GGT, urea N, creatinine, uric acid, and serum ammonium (protein precipitation method) were purchased from Nanjing Jiancheng Bioengineering Institute (Nanjing, China).

Urine samples were collected from each cow on the last 3 $\mathrm{d}$ of each experimental week [9]. Grab samples of midstream urine were collected between 1100 and $1145 \mathrm{~h}$ from each cow after eliciting micturition by manual stimulation of the vulva. 
Table 2. Schematic of experimental design and application of treatments

\begin{tabular}{|c|c|c|c|c|c|c|c|c|c|c|c|}
\hline \multirow{3}{*}{ Cow } & \multirow{3}{*}{$\begin{array}{c}\text { Preliminary } \\
-1\end{array}$} & \multicolumn{10}{|c|}{ Week } \\
\hline & & \multicolumn{4}{|c|}{ Period 1} & \multicolumn{2}{|c|}{ Washout } & \multicolumn{4}{|c|}{ Period 2} \\
\hline & & 1 & 2 & 3 & 4 & 5 & 6 & 7 & 8 & 9 & 10 \\
\hline & 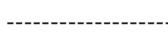 & $-\cdots$ & ---- & - & $---\mathrm{Al}_{\mathrm{r}}$ & $\mathrm{NH}_{4} \mathrm{C}$ & - & 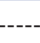 & ---- & 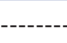 & ---- \\
\hline 10,658 & W & 0 & 150 & 300 & 450 & W & W & 0 & 0 & 0 & 0 \\
\hline 10,662 & W & 0 & 150 & 300 & 450 & W & W & 0 & 0 & 0 & 0 \\
\hline 10,725 & W & 0 & 0 & 0 & 0 & W & W & 0 & 150 & 300 & 450 \\
\hline 10,714 & W & 0 & 0 & 0 & 0 & W & W & 0 & 150 & 300 & 450 \\
\hline
\end{tabular}

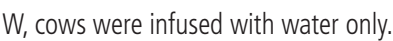

For $0 \mathrm{~g} / \mathrm{d}$ of $\mathrm{NH}_{4} \mathrm{Cl}$, cows were infused with water, too.

Urine $\mathrm{pH}$ was determined immediately by a portable $\mathrm{pH}$ meter (Seven Go portable pH meter, Mettler Toledo, Switzerland). An aliquot $(50 \mathrm{~mL})$ was stored at $4^{\circ} \mathrm{C}$; other $10-\mathrm{mL}$ aliquots were diluted immediately with $40 \mathrm{~mL}$ of $0.036 \mathrm{~N} \mathrm{H}_{2} \mathrm{SO}_{4}$ and stored at $-20^{\circ} \mathrm{C}$ for analysis of urine urea nitrogen (UUN), creatinine, urine ammonium, allantoin and uric acid. Urine samples (50 $\mathrm{mL}$ aliquots) from each cow were pooled together. A 10-mL urine subsample and serum samples stored at $-20^{\circ} \mathrm{C}$ were analyzed for $\mathrm{Na}^{+}$(ion-selective electrode), $\mathrm{K}^{+}$ (ion-selective electrode), $\mathrm{Cl}^{-}$(ion-selective electrode), $\mathrm{Ca}^{2+}$ (o-cresolphthalein complexone), $\mathrm{PO}_{4}^{3-}$ (molybdate reaction), and $\mathrm{Mg}^{2+}$ (xylidyl blue reaction) concentrations with an electrolyte analyzer (AC9000, Audicom medical technology co., LTD, Shanghai, China). Allantoin and uric acid were measured using the procedure described in Chen and Gomes [31]. Assay kits for UUN (urease method), creatinine (picric acid colorimetric method) and urine ammonium (protein precipitation method) were purchased from Nanjing Jiancheng Bioengineering Institute (Nanjing, China). Urine volumes used to compute daily excretion of UUN, urine ammonium, allantion, and uric acid were estimated as $(\mathrm{BW} \times 29) /$ urine creatinine concentration $(\mathrm{mg} / \mathrm{L})$ as described by Valadares et al [32]. The creatinine clearance rate $(\mathrm{L} / \mathrm{min})$ was calculated using the formula described by Spek et al [33].

\section{Statistical analysis}

Data were analyzed statistically by using PROC MIXED of SAS (version 9.3, SAS Institute Inc., Cary, NC, USA) as described by Drackley et al [25]. The model for an observation on cow performance, $\mathrm{y}_{\mathrm{ikkl}}$ was as follows:

$$
\mathrm{y}_{\mathrm{ijkl}}=\mu+\mathrm{t}_{\mathrm{i}}+\mathrm{p}_{\mathrm{j}}+c_{\mathrm{k}}+\varepsilon_{\mathrm{ijk}}+\mathrm{a}_{1}+\mathrm{at}_{\mathrm{il}}+\mathrm{e}_{\mathrm{ijkl}}
$$

Where $t_{\mathrm{i}}$ is the effect of treatment (control or $\mathrm{NH}_{4} \mathrm{Cl}$, considered fixed), $p_{j}$ is the effect of period $(j=1,2$, considered random $), c_{k}$ is the effect of the $k^{\prime}$ th cow $(k=1,2, \ldots 4$, considered random), and $\varepsilon_{\mathrm{ijk}}$ is the main plot error modeled as an interaction of cow with period and treatment. The fixed effect of amount, $\mathrm{a}_{\mathrm{b}}$, is confounded with the passage of time over the
$4 \mathrm{wk}$ in which this factor was applied (Table 2). As noted by Drackley et al [25], it is expected that cows receiving the wateronly infusion over the $4 \mathrm{wk}$ would have relatively constant performance and metabolism. Therefore, the interaction at ${ }_{\mathrm{il}}$ is the element of interest in this model, where the differences between treated cows and control cows over the $4 \mathrm{wk}$ in which the amount of $\mathrm{NH}_{4} \mathrm{Cl}$ was stepped up can be determined.

To model effects of infusion amount and its interaction with treatment, the REPEATED statement within PROC MIXED of SAS was used with cow (period $\times$ treatment) as the subject effect. For all variables, the covariance structure leading to the best fit of the model was the compound symmetry option. Polynomial contrasts were constructed to partition the treatment by amount interaction into single degree of freedom interactions of the linear and quadratic effects of amount with treatment, and the p-values associated with these contrasts were tabulated. Degrees of freedom were determined by using the Kenward-Roger method [34]. Model residuals were examined and all variables were normally distributed. Least squares means were calculated and are presented with their standard errors throughout. Significance was declared at $\mathrm{p}<$ 0.05 and trends at $0.05<\mathrm{p}<0.10$.

\section{RESULTS}

\section{DCAD, DMI, and health}

The DCAD of the base diet was $279 \mathrm{mEq} / \mathrm{kg}$ DM using the DCAD formula $(\mathrm{Na}+\mathrm{K}-\mathrm{Cl}-\mathrm{S}) / \mathrm{kg}$ of DM. $\mathrm{NH}_{4} \mathrm{Cl}$ infusion added the equivalent of $0,128,330$, and $536 \mathrm{mEq} / \mathrm{kg} \mathrm{DM}$ of $\mathrm{Cl}$ from the $0,150,300$, and $450 \mathrm{~g} / \mathrm{d}$ treatments. Accordingly, based on actual DMI, the DCAD of the 4 treatments were $279,151,-51$, and $-257 \mathrm{mEq} / \mathrm{kg} \mathrm{DM}$, respectively. Data for measured variables are reported and discussed in terms of these DCAD values.

Mean DMI decreased linearly as DCAD decreased (Table 3). During both periods 1 and 2, when infusion amount came to $300 \mathrm{~g} / \mathrm{d}$, the treatment cows began to have severely depressed DMI. By the last day of period 2, the 2 treatment cows were deemed too sick to complete the trial. Blood samples were 
Table 3. Effects of low DCAD on dry matter intake and performance of lactating dairy cows

\begin{tabular}{|c|c|c|c|c|c|c|c|}
\hline \multirow{2}{*}{ Item } & \multicolumn{4}{|c|}{ DCAD (mEq/kg DM) } & \multirow{2}{*}{ SEM } & \multicolumn{2}{|c|}{ Treatment by amount, $p$ value } \\
\hline & 279 & 151 & -51 & -257 & & Linear & Quadratic \\
\hline DMI $(\mathrm{kg} / \mathrm{d})$ & 21.6 & 21.9 & 17.0 & 15.7 & 1.58 & 0.0001 & 0.376 \\
\hline $\operatorname{Milk}(\mathrm{kg} / \mathrm{d})$ & 30.2 & 30.1 & 27.6 & 17.8 & 2.94 & 0.001 & 0.060 \\
\hline $4 \% F_{C M}^{11}(\mathrm{~kg} / \mathrm{d})$ & 29.4 & 30.1 & 26.2 & 17.4 & 2.92 & 0.002 & 0.080 \\
\hline$E\left(M^{2)}(\mathrm{kg} / \mathrm{d})\right.$ & 32.2 & 32.6 & 28.9 & 19.4 & 3.07 & 0.002 & 0.084 \\
\hline Fat $(\%)$ & 3.80 & 4.00 & 3.66 & 3.77 & 0.071 & 0.374 & 0.512 \\
\hline Fat (kg/d) & 1.16 & 1.20 & 1.01 & 0.68 & 0.118 & 0.003 & 0.120 \\
\hline Protein (\%) & 3.40 & 3.26 & 3.43 & 3.94 & 0.149 & 0.002 & 0.022 \\
\hline Protein (kg/d) & 1.02 & 0.98 & 0.95 & 0.66 & 0.082 & 0.008 & 0.141 \\
\hline Lactose (\%) & 4.86 & 4.90 & 4.85 & 4.41 & 0.116 & $<0.0001$ & 0.004 \\
\hline Lactose $(\mathrm{kg} / \mathrm{d})$ & 1.48 & $1.48 a$ & 1.34 & 0.80 & 0.162 & 0.0004 & 0.039 \\
\hline MUN (mg/dL) & 21.04 & 22.77 & 22.69 & 27.03 & 1.280 & 0.002 & 0.703 \\
\hline Total solids (\%) & 11.98 & 12.10 & 11.88 & 12.18 & 2.797 & 0.611 & 0.683 \\
\hline Solids-not-fat (\%) & 8.54 & 8.45 & 8.55 & 8.84 & 0.085 & 0.258 & 0.336 \\
\hline
\end{tabular}

DCAD, dietary cation anion difference; DM, dry matter; SEM, standard error of the mean; DMI, dry matter intake; FCM, fat-corrected milk; ECM, energy-corrected milk; MUN, milk urea nitrogen.

1) $4 \%$ FCM $(\mathrm{kg} / \mathrm{d})=0.4 \times$ milk $(\mathrm{kg} / \mathrm{d})+15 \times$ fat $(\mathrm{kg} / \mathrm{d})$, (NRC [52]).

2) $E C M(\mathrm{~kg} / \mathrm{d})=0.327 \times$ milk $(\mathrm{kg} / \mathrm{d})+12.95 \times$ fat $(\mathrm{kg} / \mathrm{d})+7.65 \times$ protein $(\mathrm{kg} / \mathrm{d})$.

obtained and cows received medical attention. After receiving therapy for $1 \mathrm{wk}$, the 2 sick cows had recovered.

Rumen $\mathrm{pH}(6.06,6.16,5.97,5.88)$ tended to decrease linearly $(\mathrm{p}=0.084)$ and concentration of ammonia $(14.97,20.81$, $25.54,39.30 \mathrm{mg} / \mathrm{L}$ ) in the rumen contents increased linearly $(\mathrm{p}<0.0001)$ as infusion increased [35].

\section{Milk yield and composition}

Effects of decreasing DCAD on milk yield and composition are shown in Table 3. Yields of milk, $4 \%$ fat-corrected milk (FCM), and energy-corrected milk (ECM) decreased linearly. The quadratic effects approached significance, indicating that the magnitude of decrease tended to be greater when DCAD was from -51 to $-257 \mathrm{mEq} / \mathrm{kg}$ DM. Similarly, milk fat yield and milk protein yield decreased linearly. Concentrations of milk protein and milk urea nitrogen (MUN) increased linearly with decreasing DCAD. Milk lactose concentration decreased as DCAD decreased, with decrease being greater as DCAD was from $-51 \mathrm{mEq} / \mathrm{kg} \mathrm{DM}$ or greater (quadratic effect, $\mathrm{p}=$ 0.004). Yield of milk lactose decreased in a quadratic fashion similar to milk lactose concentration, with the largest decrease when DCAD was $-257 \mathrm{mEq} / \mathrm{kg}$ DM. No effects were observed on concentrations of milk fat, total solids, and solids-not fat.

\section{Serum and urine minerals}

Table 4 presents mean values of serum ions, urine irons and urine metabolites of dairy cows as DCAD decreased. Urine $\mathrm{pH}$ decreased linearly and the quadratic effects approached significance, indicating that the magnitude of decreases tended to increase when DCAD was -51 or $-257 \mathrm{mEq} / \mathrm{kg}$ DM. Concentration of $\mathrm{Cl}^{-}$in serum increased linearly; the quadratic effect approached significance because the magnitude of increase tended to be greater when DCAD was $-257 \mathrm{mEq} / \mathrm{kg}$ DM. Concentration of $\mathrm{Ca}^{2+}$ in serum tended to decrease linearly, but $\mathrm{Mg}^{2+}$ in serum tended to increase linearly with decreasing DCAD. Concentration of $\mathrm{PO}_{4}^{3-}$ in serum increased quadratically as DCAD decreased, with the largest increases when DCAD was $-257 \mathrm{mEq} / \mathrm{kg}$ DM. Calculated urine volume increased linearly as DCAD decreased. Daily excretion of $\mathrm{Cl}^{-}, \mathrm{Ca}^{2+}, \mathrm{PO}_{4}^{3-}$, $\mathrm{UUN}$, and urine ammonium increased linearly as DCAD decreased, whereas daily excretion of $\mathrm{K}^{+}$ and urine acid in urine decreased linearly.

\section{Serum metabolites and enzymes}

Blood biochemical indices of dairy cows as DCAD decreased are shown in Table 5. Linear increases were observed in serum activities of ALT, AST, and GGT, as well as the concentration of blood urea nitrogen, as DCAD decreased. However, the concentration of uric acid in serum decreased linearly with decreasing DCAD. Concentration of creatinine in serum tended to increase linearly while concentration of serum ammonium was unaffected with decreasing DCAD.

\section{DISCUSSION}

Urea and $\mathrm{NH}_{4} \mathrm{Cl}$, as sources of NPN, undergo different dissociation processes in the rumen. When urea is hydrolyzed by microbial ureases it forms $\mathrm{NH}_{3}$, but $\mathrm{NH}_{4} \mathrm{Cl}$ dissociates into $\mathrm{NH}_{4}^{+}$and $\mathrm{Cl}^{-}$. The $\mathrm{NH}_{3}$ is converted to $\mathrm{NH}_{4}^{+}$with the addition of a hydrogen ion, and rumen $\mathrm{pH}$ is unchanged or elevated [22] and vice versa. Bartley et al [21] reported that rumen $\mathrm{pH}$ was more related to ammonia toxicity than was rumen ammonia. Visek [36] showed that elevated $\mathrm{pH}$ facilitates greater absorption of ammonia across the rumen wall. In our study, 
Table 4. Effects of low DCAD on serum ions, urine irons and urine metabolites of lacating dairy cows

\begin{tabular}{|c|c|c|c|c|c|c|c|}
\hline \multirow{2}{*}{ Item } & \multicolumn{4}{|c|}{ DCAD (mEq/kg DM) } & \multirow{2}{*}{ SEM } & \multicolumn{2}{|c|}{ Treatment by amount, $\mathrm{p}$ value } \\
\hline & 279 & 151 & -51 & -257 & & Linear & Quadratic \\
\hline \multicolumn{8}{|l|}{ Serum ions (mmol/L) } \\
\hline $\mathrm{K}^{+}$ & 4.23 & 4.34 & 4.32 & 4.08 & 0.059 & 0.472 & 0.090 \\
\hline $\mathrm{Na}^{+}$ & 137.5 & 137.8 & 138.4 & 142.4 & 1.14 & 0.138 & 0.137 \\
\hline $\mathrm{Cl}^{-}$ & 95.6 & 98.0 & 99.1 & 109.6 & 3.10 & 0.003 & 0.072 \\
\hline $\mathrm{Ca}^{2+}$ & 2.30 & 2.30 & 2.28 & 2.19 & 0.026 & 0.080 & 0.852 \\
\hline $\mathrm{PO}_{4}^{3-}$ & 1.68 & 1.67 & 1.78 & 2.25 & 0.137 & 0.020 & 0.029 \\
\hline $\mathrm{Mg}^{2+}$ & 0.99 & 0.98 & 0.98 & 1.01 & 0.007 & 0.056 & 0.669 \\
\hline Urine pH & 7.92 & 7.54 & 5.83 & 5.70 & 0.573 & $<0.0001$ & 0.086 \\
\hline \multicolumn{8}{|l|}{ Urine ions (mmol/d) } \\
\hline $\mathrm{K}^{+}$ & 5,710 & 4,932 & 5,723 & 4,047 & 397.5 & 0.028 & 0.349 \\
\hline $\mathrm{Na}^{+}$ & 3,001 & 2,325 & 3,168 & 3,704 & 284.4 & 0.441 & 0.270 \\
\hline $\mathrm{Cl}^{-}$ & 3,356 & 5,232 & 7,854 & 7,716 & $1,078.32$ & 0.0003 & 0.444 \\
\hline $\mathrm{Ca}^{2+}$ & 14 & 100 & 214 & 731 & 160.8 & 0.0009 & 0.100 \\
\hline $\mathrm{PO}_{4}^{3-}$ & 14.2 & 11.0 & 27.8 & 190.0 & 43.2 & 0.016 & 0.070 \\
\hline $\mathrm{Mg}^{2+}$ & 114.5 & 123.1 & 151.2 & 154.4 & 10.0 & 0.790 & 0.517 \\
\hline Urine volume $(\mathrm{kg} / \mathrm{d})$ & 42.7 & 44.8 & 92.5 & 127.9 & 20.5 & 0.025 & 0.709 \\
\hline Creatinine clearance (L/min) & 1.86 & 1.72 & 1.76 & 1.52 & 0.071 & 0.104 & 0.700 \\
\hline UUN (mmol/d) & 4,465 & 4,541 & 5,274 & 6,451 & 562.8 & 0.001 & 0.363 \\
\hline Urine ammonium (mmol/d) & 30 & 80 & 826 & 2541 & 586.1 & 0.004 & 0.147 \\
\hline Allantoin (mmol/d) & 167 & 246 & 465 & 367 & 65.8 & 0.287 & 0.510 \\
\hline Uric acid (mmol/d) & 46.3 & 48.9 & 49.4 & 29.8 & 4.64 & 0.015 & 0.129 \\
\hline
\end{tabular}

DCAD, dietary cation anion difference; DM, dry matter; SEM, standard error of the mean; UUN, urine urea nitrogen.

although ruminal ammonia concentration increased markedly, ruminal $\mathrm{pH}$ decreased as infusion increased. Lower rumen $\mathrm{pH}$ can trap ammonia within the rumen, and high rumen ammonia does not produce sublethal or lethal ammonia toxicity [23]. Rumen ammonia dissociated from $\mathrm{NH}_{4} \mathrm{Cl}$ would be absorbed gradually through ruminal epithelium cell to blood and then excreted into urine. Therefore, the concentration of ammonia in serum was not affected by the infusion of $\mathrm{NH}_{4} \mathrm{Cl}$, and signs consistent with ammonia toxicity did not appear. Therefore, we attribute most of the negative effects of increasing $\mathrm{NH}_{4} \mathrm{Cl}$ infusion to the negative DCAD and resulting uncompensated metabolic acidosis.

Decreasing dietary DCAD had negative effects on the latelactating cows in this study. The linear decreases of milk yield, 4\% FCM, ECM, milk fat yield, milk protein yield, and milk lactose yield likely were attributable in large part to the decrease of DMI. Because $\mathrm{NH}_{4} \mathrm{Cl}$ was infused into the rumen of lactating dairy cows, the decrease of DMI could not have been caused by palatability issues. Instead, decreased DMI likely was attributable to the metabolic acidosis that was induced by low DCAD. Cows infused with the highest amount of $\mathrm{NH}_{4} \mathrm{Cl}$ showed obvious signs of distress due to the negative DCAD.

Dietary cation-anion balance has well-known effects on acid-base status and production of cows and other animals. The optimum DCAD in ruminants depends on their production status. Block [1] reported that the incidence of milk fever was reduced from $47.4 \%$ in cows fed a cationic diet to $0 \%$ when cows received an anionic diet during the dry period. Conversely, Tucker et al [3] showed that a cationic diet (200

Table 5. Effects of low DCAD on biochemical indices of blood of lacating dairy cows

\begin{tabular}{|c|c|c|c|c|c|c|c|}
\hline \multirow{2}{*}{ Item } & \multicolumn{4}{|c|}{ DCAD (mEq/kg DM) } & \multirow{2}{*}{ SEM } & \multicolumn{2}{|c|}{ Treatment by amount, $p$ value } \\
\hline & 279 & 151 & -51 & -257 & & Linear & Quadratic \\
\hline Alanine aminotransferase (U/L) & 26 & 28 & 28 & 46 & 4.7 & 0.011 & 0.080 \\
\hline Aspartate aminotransferase (U/L) & 79 & 85 & 95 & 114 & 7.7 & 0.0004 & 0.261 \\
\hline$\gamma$-Glutamyl transferase (mmol/L) & 31.0 & 30.9 & 31.9 & 36.2 & 1.25 & 0.003 & 0.169 \\
\hline Urea N (mmol/L) & 4.88 & 5.54 & 5.40 & 6.36 & 0.307 & 0.005 & 0.704 \\
\hline Uric acid (umol/L) & 37.8 & 32.7 & 25.6 & 20.6 & 3.80 & 0.046 & 0.077 \\
\hline Creatinine (umol/L) & 53 & 57 & 56 & 67 & 3.0 & 0.084 & 0.832 \\
\hline Ammonia (umol/L) & 123.6 & 122.1 & 111.1 & 141 & 6.2 & 0.096 & 0.564 \\
\hline
\end{tabular}

DCAD, dietary cation anion difference; DM, dry matter; SEM, standard error of the mean. 
$\mathrm{mEq} / \mathrm{kg} \mathrm{DM}$ ) resulted in greater milk yield than when diets containing $-100,0$, or $100 \mathrm{mEq} / \mathrm{kg}$ were fed. In a meta-analysis, $\mathrm{Hu}$ and Murphy [37] reported that milk yield was greatest when the DCAD $(\mathrm{Na}+\mathrm{K}-\mathrm{Cl})$ was $340 \mathrm{mEq} / \mathrm{kg}$ of DM, 4.0\% FCM production was highest at $490 \mathrm{mEq} / \mathrm{kg}$ of DM DCAD, and DMI was maximized at $400 \mathrm{mEq} / \mathrm{kg}$ of DM DCAD. In our study, DMI, milk yield, ECM yield, and 4\% FCM yield did not decrease when DCAD decreased from 279 to $151 \mathrm{mEq} / \mathrm{kg}$ $\mathrm{DM}$, but decreased markedly when DCAD was $-51 \mathrm{mEq} / \mathrm{kg}$ DM. The optimum DCAD may relate to stage of lactation and milk production, so lack of production change when DCAD was $151 \mathrm{mEq} / \mathrm{kg}$ DM may be attributable to the late stage of lactation (days in milk $=357 \pm 2 \mathrm{~d}$ ) of our cows.

The concentration of milk protein measured by infrared analysis in our study represents $\mathrm{CP}$ or total nitrogen rather than true protein. Although the concentration of milk total protein increased with the higher infusion amounts, the concentration of MUN also increased with decreasing DCAD. So, the concentration of milk true protein likely did not increase with increasing amount of $\mathrm{NH}_{4} \mathrm{Cl}$ infused. It seemed that $\mathrm{NH}_{4}^{+}$ as a source of NPN had little influence on the synthesis of milk protein under conditions of our study.

In general, responses of mineral ions in serum and ion excretion in urine followed well described patterns. Increased serum $\mathrm{Cl}^{-}$concentration at the highest infusion rate may have resulted from the inability of the kidneys to excrete additional $\mathrm{Cl}^{-}$, as the amounts excreted were similar for DCAD of -151 and -257 . The kidneys can efficiently eliminate excess anions from the blood, thus infusion of $\mathrm{NH}_{4} \mathrm{Cl}$ induced a sharp reduction in urinary $\mathrm{pH}$. The effect of increased dietary anions ( $\mathrm{Cl}$ and $\mathrm{S}$ ) to decrease urine $\mathrm{pH}$ is well documented [38-40]. Monitoring the $\mathrm{pH}$ of urine is considered a sensitive method for assessing the acid-base balance of animals [41].

Urinary excretion of $\mathrm{Ca}^{2+}$ increased sharply with decreasing DCAD, with serum $\mathrm{Ca}^{2+}$ concentration decreasing at the lowest DCAD. Previous studies revealed that decreased DCAD increased urinary $\mathrm{Ca}^{2+}$ excretion in lactating [42], nonlactating [43], and close-up prepartum [44,45] dairy cows. The metabolic acidosis induced by the negative DCAD diets in this study likely decreased $\mathrm{Ca}^{2+}$ reabsorption via the kidney tubules, so more $\mathrm{Ca}^{2+}$ was excreted into the urine. Although negative DCAD diets prepartum are believed to increase serum $\mathrm{Ca}^{2+}$ in newly calved cows by increasing Ca mobilization from bone to maintain blood $\mathrm{Ca}^{2+}[46]$, the extreme acidosis induced in this study likely created more urinary excretion of $\mathrm{Ca}^{2+}$ than could be maintained in the blood.

Because bone hydroxyapatite is the source of increased $\mathrm{Ca}^{2+}$ concentrations excreted in urine, increased concentration of $\mathrm{PO}_{4}{ }^{3-}$ in serum and increased urinary $\mathrm{PO}_{4}^{3-}$ excretion was expected. Block [1] observed an increase in concentration of serum $\mathrm{PO}_{4}^{3-}$ during the peripartum period for cows receiving anionic diets. Metabolic acidosis induced by low DCAD diets may result in an increase in parathyroid hormone release, which in turn would increase phosphorus mobilized from bone, increase serum $\mathrm{PO}_{4}^{3-}$, and result in excess $\mathrm{PO}_{4}{ }^{3-}$ being lost in urine. In contrast, other studies $[40,47,48]$ reported no significant effect of prepartum DCAD on serum $\mathrm{PO}_{4}{ }^{3-}$. The different results may be attributable to the different lactation stage of test cows and differences in the degree of acidosis induced.

The liver as a main organ in ruminant metabolism is sensitive to nutritional modifications. Serum ALT, AST, and GGT are frequently used as markers of liver damage resulting from metabolic disease or stressors $[49,50]$. Activities of ALT, AST, and GGT in serum are increased when liver is damaged, resulting in liberation of these cellular enzymes into the serum. In our trial, ALT, AST, and GGT activities increased linearly with decreasing DCAD, suggesting that the cows incurred some degree of liver damage. Renal function indices such as serum urea and creatinine are used to evaluate the functional integrity of the kidney, with elevated values being an indication of defective functional state [51]. Linearly increased serum urea and the tendency to linearly increase creatinine concentrations observed in this study also may imply some degree of renal toxicity imposed by negative DCAD. However, increasing ruminal infusion of ammonium ions and decreased DMI may have resulted in excess ammonia and more urea formation, which confounds the interpretation.

\section{CONCLUSION}

Negative DCAD caused by acute changes in the amount of $\mathrm{NH}_{4} \mathrm{Cl}$ infused into the rumen had negative influence on performance of lactating dairy cows. In particular, a DCAD of $-51 \mathrm{mEq} / \mathrm{kg} \mathrm{DM}$ as induced by infusion of $300 \mathrm{~g} / \mathrm{d}$ of $\mathrm{NH}_{4} \mathrm{Cl}$ caused severe metabolic acidosis, decreased DMI, and decreased milk yield. The most negative DCAD also caused some indications of liver and kidney damage. Infusion of $\mathrm{NH}_{4} \mathrm{Cl}$ did not affect concentration of milk true protein and did not seem to cause ammonia toxicity under the conditions of the present study. While a small amount of $\mathrm{NH}_{4} \mathrm{Cl}$ that does not create a negative DCAD can be tolerated, short-term ingestion of amounts that create a negative DCAD could be detrimental in lactating dairy cows. As a result, we recommended that daily $\mathrm{NH}_{4} \mathrm{Cl}$ intake by lactating dairy cows should not exceed $300 \mathrm{~g}$, and a more appropriate daily intake may be $150 \mathrm{~g}$.

\section{CONFLICT OF INTEREST}

We certify that there is no conflict of interest with any financial organization regarding the material discussed in the manuscript. Liu S is an employee of China Feed Industry Association, and Zhang $\mathrm{K}$ is an employee of Beijing Sino Farm. 


\section{ACKNOWLEDGMENTS}

The authors express appreciation to Gary Crow (Department of Animal Science, University of Manitoba, Winnipeg, Canada) for statistical evaluation of data. We also thank the personnel of Sinofarm (Beijing, China) for feeding, milking, and care of cows. Financial support for this study was provided by grant (No.2012BAD12B02-5) from Ministry of Science and Technology of China, Quality and Safety Supervision of Agricultural Products (Feed) Project: Safety Evaluation of Ruminant Feed, and the Agricultural Science and Technology Innovation Program (ASTIP-IAS07).

\section{REFERENCES}

1. Block E. Manipulating dietary anions and cations for prepartum dairy cows to reduce incidence of milk fever. J Dairy Sci 1984;67:2939-48.

2. Oetzel GR, Olson JD, Curtis CR, Fettman MJ. Ammonium chloride and ammonium sulfate for prevention of parturient paresis in dairy cows. J Dairy Sci 1988;71:3302-9.

3. Tucker WB, Harrison GA, Hemken RW. Influence of dietary cation-anion balance on milk, blood, urine, and rumen fluid in lactating dairy cattle. J Dairy Sci 1988;71:346-54.

4. West JW, Mullinix BG, Sandifer TG. Changing dietary electrolyte balance for dairy cows in cool and hot environments. J Dairy Sci 1991;74:1662-74.

5. West JW, Haydon KD, Mullinix BG, Sandifer TG. Dietary cation-anion balance and cation source effects on production and acid-base status of heat-stressed cows. J Dairy Sci 1992;75: 2776-86.

6. Escobosa A, Coppock CE, Rowe LD, Jr., Jenkins WL, Gates CE. Effects of dietary sodium bicarbonate and calcium chloride on physiological responses of lactating dairy cows in hot weather. J Dairy Sci 1984;67:574-84.

7. Yen JT, Pond WG, Prior RL. Calcium chloride as a regulator of feed intake and weight gain in pigs. J Anim Sci 1981;52:77882.

8. Leoschke W, Elvehjem C. Prevention of urinary calculi formation in mink by alteration of urinary pH. Exp Biol Med 1954; 85:42-4.

9. Goff JP, Ruiz R, Horst RL. Relative acidifying activity of anionic salts commonly used to prevent milk fever. J Dairy Sci 2004;87: 1245-55.

10. Gelfert CC, Loptien A, Montag N, Staufenbiel R. Duration of the effects of anionic salts on the acid-base status in cows fed different anionic salts only once daily. Res Vet Sci 2009;86:52932.

11. Augustinsson O, Johansson K. Ammonium chloride induced acidosis and aldosterone secretion in the goat. Acta Physiol Scand 1986;128:535-40.

12. Jones ML, Streeter RN, Goad CL. Use of dietary cation anion difference for control of urolithiasis risk factors in goats. Am J Vet Res 2009;70:149-55.

13. Mavangira V, Cornish JM, Angelos JA. Effect of ammonium chloride supplementation on urine $\mathrm{pH}$ and urinary fractional excretion of electrolytes in goats. J Am Vet Med Assoc 2010;237: 1299-304.

14. Crookshank H. Effect of ammonium salts on the production of ovine urinary calculi. J Anim Sci 1970;30:1002-4.

15. Shaw $\mathrm{DH}$. Acute response of urine $\mathrm{pH}$ following ammonium chloride administration to dogs. Am J Vet Res 1989;50:182930.

16. Taton GF, Hamar DW, Lewis LD. Evaluation of ammonium chloride as a urinary acidifier in the cat. J Am Vet Med Assoc 1984;184:433-6.

17. Hueller R, Cooper S, Toopliff D. Effect of dietary cationanion difference on acid-base status and energy digestibility in sedentary horses fed varying levels and types of starch. J Equine Vet Sci 2001;21:498-502.

18. Osther PJ, Engel K, Kildeberg P. Renal response to acute acid loading - An organ physiological approach. Scand J Urol Nephrol 2004;38:62-8.

19. Iwabuchi S, Suzuki K, Abe I, Asano R. Comparison of the effects of isotonic and hypertonic sodium bicarbonate solutions on acidemic calves experimentally induced by ammonium chloride administration. J Vet Med Sci 2003;65:1369-71.

20. Crookshank H, Smalley H, Furr D, Ellis GF. Ammonium chloride and ammonium sulfate in cattle feedlot finishing rations. J Anim Sci 1973;36:1007-9.

21. Bartley EE, Davidovich AD, Barr GW, et al. Ammonia toxicity in cattle. I. Rumen and blood changes associated with toxicity and treatment methods. J Anim Sci 1976;43:835-41.

22. Kertz AF, Koepke MK, Davidson LE, et al. Factors influencing intake of high urea-containing rations by lactating dairy cows. J Dairy Sci 1982;65:587-604.

23. Kertz AF, Davidson LE, Cords BR, Puch HC. Ruminal infusion of ammonium chloride in lactating cows to determine effect of $\mathrm{pH}$ on ammonia trapping. J Dairy Sci 1983;66:2597-601.

24. Khas-Erdene Q, Wang JQ, Bu DP, et al. Short communication: responses to increasing amounts of free alpha-linolenic acid infused into the duodenum of lactating dairy cows. J Dairy Sci 2010;93:1677-84.

25.Drackley JK, Overton TR, Ortiz-Gonzalez G, et al. Responses to increasing amounts of high-oleic sunflower fatty acids infused into the abomasum of lactating dairy cows. J Dairy Sci 2007; 90:5165-75.

26. Wu Z, Bernard JK, Zanzalari KP, Chapman JD. Effect of feeding a negative dietary cation-anion difference diet for an extended time prepartum on postpartum serum and urine metabolites and performance. J Dairy Sci 2014;97:7133-43.

27. Association of Official Analytical Chemistry (AOAC). Official methods of analysis, 17th edition. Arlington, VA, USA: AOAC International; 2000. 
28. Van Soest Pv, Robertson J, Lewis B. Methods for dietary fiber, neutral detergent fiber, and nonstarch polysaccharides in relation to animal nutrition. J Dairy Sci 1991;74:3583-97.

29.Laporte MF, Paquin P. Near-infrared analysis of fat, protein, and casein in cow's milk. J Agric Food Chem 1999;47:2600-5.

30. Bu DP, Wang JQ, Dhiman TR, Liu SJ. Effectiveness of oils rich in linoleic and linolenic acids to enhance conjugated linoleic acid in milk from dairy cows. J Dairy Sci 2007;90:998-1007.

31. Chen XB, Gomes M. Estimation of microbial protein supply to sheep and cattle based on urinary excretion of purine derivatives-an overview of the technical details. Aberdeen UK: International Feed Resources Unit, Rowett Research Institute; 1992.

32. Valadares RFD, Broderick GA, Filho SCV, Clayton MK. Effect of replacing alfalfa silage with high moisture corn on ruminal protein synthesis estimated from excretion of total purine derivatives. J Dairy Sci 1999;82:2686-96.

33.Spek JW, Bannink A, Gort G, Hendriks WH, Dijkstra J. Interaction between dietary content of protein and sodium chloride on milk urea concentration, urinary urea excretion, renal recycling of urea, and urea transfer to the gastrointestinal tract in dairy cows. J Dairy Sci 2013;96:5734-45.

34.Littell RC, Henry PR, Ammerman CB. Statistical analysis of repeated measures data using SAS procedures. J Anim Sci 1998;76:1216-31.

35. Wang K, Zhao P, Liu W, et al. Effect of ammonium chloride on ruminal fermentation characteristic and nutrient apparent digestibility of dairy cows. J Northeast Agric Univ 2016;47:705.

36. Visek WJ. Some aspects of ammonia toxicity in animal cells. J Dairy Sci 1968;51:286-95.

37. Hu W, Murphy MR. Dietary cation-anion difference effects on performance and acid-base status of lactating dairy cows: a meta-analysis. J Dairy Sci 2004;87:2222-9.

38. Joyce PW, Sanchez WK, Goff JP. Effect of anionic salts in prepartum diets based on alfalfa. J Dairy Sci 1997;80:2866-75.

39. Pehrson B, Svensson C, Gruvaeus I, Virkki M. The influence of acidic diets on the acid-base balance of dry cows and the effect of fertilization on the mineral content of grass. J Dairy Sci 1999;82:1310-6.

40.Shahzad MA, Sarwar M, Mahr-un-Nisa. Influence of varying dietary cation anion difference on serum minerals, mineral balance and hypocalcemia in Nili Ravi buffaloes. Livest Sci 2008;113:52-61.
41. Seifi HA, Mohri M, Zadeh JK. Use of pre-partum urine $\mathrm{pH}$ to predict the risk of milk fever in dairy cows. Vet J 2004;167:2815.

42. Tucker WB, Hogue JF, Waterman DF, et al. Role of sulfur and chloride in the dietary cation-anion balance equation for lactating dairy cattle. J Anim Sci 1991;69:1205-13.

43. Tucker WB, Hogue JF, Adams GD, et al. Influence of dietary cation-anion balance during the dry period on the occurrence of parturient paresis in cows fed excess calcium. J Anim Sci 1992;70:1238-50.

44. Gaynor P, Mueller F, Miller J, et al. Parturient hypocalcemia in Jersey cows fed alfalfa haylage-based diets with different cation to anion ratios. J Dairy Sci 1989;72:2525-31.

45. Roche JR, Dalley D, Moate P, et al. Dietary cation-anion difference and the health and production of pasture-fed dairy cows 2. Nonlactating periparturient cows. J Dairy Sci 2003;86: 979-87.

46. Van Mosel M, Wouterse H, Van't Klooster AT. Effects of reducing dietary $\left(\left[\mathrm{Na}^{+}+\mathrm{K}^{+}-\left[\mathrm{Cl}^{-}+\mathrm{SO}_{4}{ }^{2-}\right]\right)\right.$ on bone in dairy cows at parturition. Res Vet Sci 1994;56:270-6.

47. Wu WX, Liu JX, Xu GZ, Ye JA. Calcium homeostasis, acidbase balance, and health status in periparturient Holstein cows fed diets with low cation-anion difference. Livest Sci 2008;117: 7-14.

48. Razzaghi A, Aliarabi H, Tabatabaei MM, et al. Effect of dietary cation-anion difference during prepartum and postpartum periods on performance, blood and urine minerals status of Holstein dairy cow. Asian-Australas J Anim Sci 2012;25:48695.

49. Gonzalez FD, Muino R, Pereira V, Campos R, Benedito JL. Relationship among blood indicators of lipomobilization and hepatic function during early lactation in high-yielding dairy cows. J Vet Sci 2011;12:251-5.

50. Kataria N, Kataria AK. Use of serum gamma glutamyl transferase as a biomarker of stress and metabolic dysfunctions in Rathi cattle of arid tract in India. J Stress Physiol Biochem 2012; 8:23-9.

51.Yakuba MT, Bilbis LS, Lawal M, Akanji MA. Evaluation of selected parameters of rat liver and kidney function following repeated administration of yohimbine. Biokemistri 2003;15: 50-6.

52. National Research Council (NRC). Nutrient requirements of dairy cattle. 7th edition. Washington, DC, USA: National Academy Press; 2001. 